\title{
Boundaries of the Community of Teachers' Implementing Mathematics Textbooks with Lesson Study and Open Approach
}

\author{
Chanika Senawongsa ${ }^{1}$, Maitree Inprasitha ${ }^{2}$, Anake Sudejamnong ${ }^{3}$ \\ ${ }^{1}$ Doctoral Program in Mathematics Education, Faculty of Education, Khon Kaen University, Khon Kaen, Thailand \\ ${ }^{2}$ Centre of Excellence in Mathematics, CHE, Si Ayutthaya RD., Bangkok, Thailand \\ ${ }^{3}$ Mathematics and Statistics Program, Faculty of Science and Technology, Suratthani Rajabhat University, Suratthani, Thailand \\ Email: chanika_s@kkumail.com,inprasitha_crme@kku.ac.th,sud_anake@hotmail.com
}

How to cite this paper: Senawongsa, C., Inprasitha, M., \& Sudejamnong, A. (2019). Boundaries of the Community of Teachers' Implementing Mathematics Textbooks with Lesson Study and Open Approach. Creative Education, 10, 1999-2012.

https://doi.org/10.4236/ce.2019.109146

Received: May 13, 2019

Accepted: September 15, 2019

Published: September 18, 2019

Copyright $\odot 2019$ by author(s) and Scientific Research Publishing Inc. This work is licensed under the Creative Commons Attribution International License (CC BY 4.0).

http://creativecommons.org/licenses/by/4.0/

\begin{abstract}
This study aimed to analyze boundaries of the community of teachers' implementing the mathematics textbooks with Lesson Study and Open Approach. For this study, Mathematics textbooks were Japanese mathematics textbooks (Thai version), consisting of mathematics problems, flow of lesson, and students' mathematical ideas. The participants were 2 expert teachers who use the textbooks in the classroom using Lesson Study and Open Approach since 2013. The data were collected in 2017 school year by using interview and classroom observation with video recording. The data were analyzed based on Wenger, McDermott, \& Snyder (2002)'s framework of community of practice. The results showed that the teachers practiced in 3 boundaries of the community: 1) within school-every week, they use the textbooks to design mathematical problems and anticipating students' ideas with their school team, then they teach the lesson and observe students' ideas in the classroom, and they reflect on students' ideas that occurred in their classroom, 2) across schools-every semester, they form team with teachers who work in different schools of the project to design/observe/reflect a classroom by using the textbooks in school open class activity, and 3) across organization boundaries - every year, they and their school network participated in the activities, the national open class, the workshop for school teachers, the national and international conference, that help them to understand students' ideas via classroom by using the textbooks and sharing with their school teachers and university experts.
\end{abstract}

\section{Keywords}

Community of Practice, Implementing Mathematics Textbooks, Lesson Study and Open Approach 


\section{Introduction}

Before entering the 21st Century, most of teachers' learning in Thailand depends upon a professional development by disseminating information to teachers through various kinds of short course training (Inprasitha, 2015, 2017). But it is not enough, they need to learn new ideas and knowledge to improve their teaching and learning, and they also need to have opportunities to try those ideas and knowledge in their classroom and reflect. Professional development should have some innovations that can improve teachers' practice in their classroom (Inprasitha, 2015, 2017; Takahashi, 2015).

Lesson Study as a professional development that originated in Japan and diffused in many countries, especially Thailand. In 2002, Center for Research in Mathematics Education Faculty of Education, Khon Kaen University started to conduct Lesson Study and Open Approach in the project for teacher professional development to elementary schools (Inprasitha, 2015). Both of Lesson Study and Open Approach impacted teachers' formal role that emphasizes teaching by telling definitions, remembering rules and doing exercises that appeared in Thai mathematics textbooks.

At the early stage of this project, Japanese mathematics textbooks (Thai version) help teachers and their team to design problem situations, instructional materials, and anticipate students' ideas, that appeared in the textbooks (Inprasitha, 2015). Teachers, who participated in professional development thought Lesson Study and OpenApproach, have opportunities to learn teaching practice in their classroom in many dimensions such as curriculum, materials, assessment, their students' thinking, etc. (Inprasitha, 2015; Takahashi, 2015). And mathematics textbooks as a resource help teachers to understand students' thinking (Inprasitha, 2015).

Thai teachers had opportunities to share their practice and learn from their community that are in accord with the definition of communities of practice by Wenger, McDermott, \& Snyder (2002). In addition, they suggested that the first skill for improving their community is to be able to "see" boundaries of the community. Thus, this research aims to analyze what boundaries are of the community of teachers' implementing the mathematics textbooks with Lesson Study and Open Approach.

\section{Lesson Study and Open Approach}

As the popularity of Lesson Study in many countries around the world, they adapted the method based on the context of country. According to Inprasitha (2010, 2011, 2015, 2017) adapted the Lesson Study and Open Approach to Thai context. He adapted "The Open-Ended Approach Method" to "Open Approach" as a new teaching approach since 2002. In 2006, the open approach was incorporated in the process of Lesson Study for improving the teaching approach in weekly (Inprasitha, 2010, 2011, 2015, 2017) as Figure 1. Thus teachers, who participated in the innovation, had opportunities to learn and try new teaching 


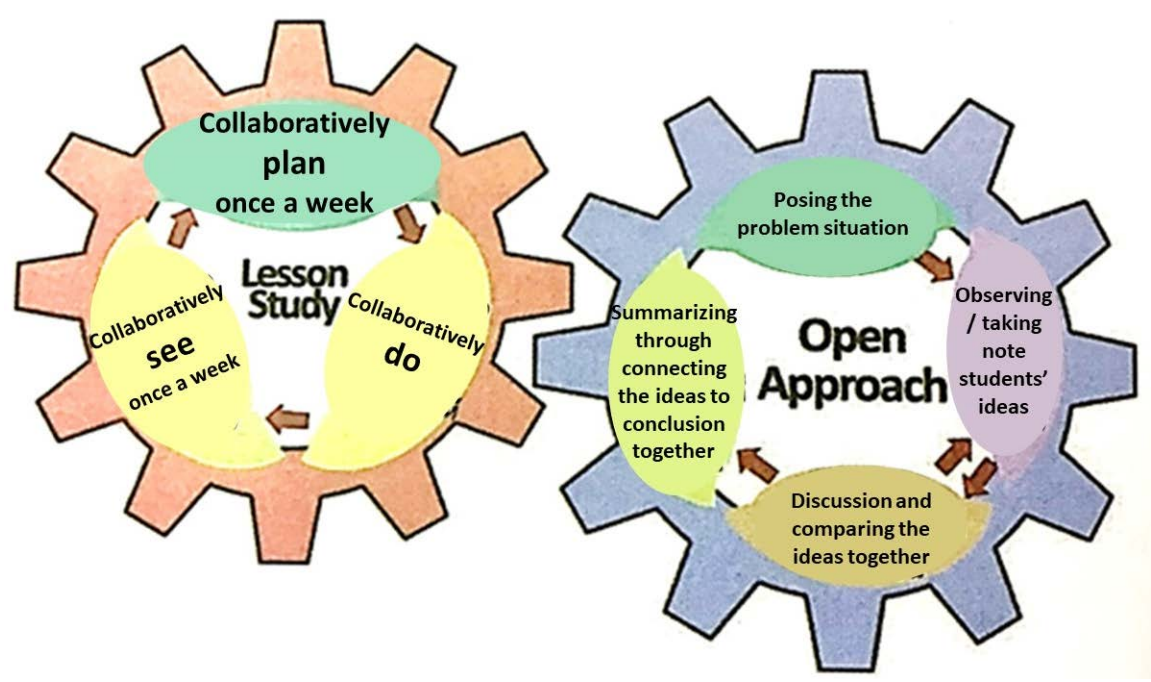

Figure 1. The weekly cycle of lesson study and open approach by Inprasitha (2010, 2015, 2017).

approach and share their experiences together.

The 4 project schools, located in the northeastern part of Thailand, were pilot schools to conduct the Lesson Study and Open Approach with a lesson study group from faculty of education, Khon Kaen University since 2006. At present, the project had more than 120 schools located in all the part of Thailand.

Each school, they form a group, consisting of classroom teachers, observer teachers, school principal, student teachers, graduate students (as school coordinators), and university experts. The group practiced in the weekly cycle of Lesson Study and Open Approach (Inprasitha, 2010, 2011, 2015, 2017) as a weekly cycle as below:

1) The group collaboratively plan lessons once a week. They designed problem situations, materials, flow of lesson, and anticipated students' ideas.

2) The group collaboratively does teach and observe in the normal classroom. The classroom teacher taught the lesson by following the steps of open approach. They observed students' ideas together.

3) The group collaboratively see/reflect the classroom. They reflected and shared the students' ideas that appeared in the classroom and how to improve the lesson.

When the group planned, taught, observed, and reflected on the classroom together, they followed 4 steps of Open Approach (Inprasitha, 2010, 2011, 2015, 2017) as below:

1) Posing the problem situation in the classroom;

2) Observing and taking note student's ideas while students solve the problem by themselves;

3) Discussing and comparing the ideas together, and support students to explain their ideas;

4) Summarizing through connecting the ideas to conclusion. 
Next section, we reviewed mathematics textbooks as a resource of mathematics problems, students' ideas, and flow of lesson for guiding teachers to plan the lesson.

\section{Implementing Mathematics Textbooks}

Mathematics textbooks are very important as representative of curriculum using in school. Shimizu \& Watanabe (2010) stated that the mathematics textbooks is a connecting point with curriculum and plays an important role in the mathematics classroom.

In the first stage of Lesson Study and Open Approach, teachers need to design problem situations that appropriated to provide students' opportunities to learn and solve the problem by themselves and they need to anticipate students' ideas (Inprasitha, Pattanajak, \& Inprasitha, 2011). Consequently, they need a tool that could be supported and guided the problem and how students' thinking, such as mathematics textbooks.

Mathematics textbooks and their guidelines for school level were used in almost Thai schools that were created by the Institute for Promotion of Teaching Science and Technology assigned by the Commission on Basic Education. Inprasitha (1997); Inprasitha, Pattanajak, \& Inprasitha (2011) analyzed the problem solving in Thai mathematics textbooks for first to ninth grade level. He found that the characteristics of textbooks especially for elementary school level are as follows: almost of the exercises and word problems contain routine exercises for drilling computational skills, require the students to write symbolic sentence before solving the problem, and have one and only one correct answer. And the structure of mathematics contents is axiomatic approach. His assumption of this pedagogy is that students are expected to master the rules, techniques or principles.

As the limitation of Thai mathematics textbooks were a barrier for helping teachers to conduct the first stage. Inprasitha, Pattanajak, \& Inprasitha (2011) stated that Thai mathematics textbooks cannot be used properly in the project of teacher professional development with Lesson Study and Open Approach. Therefore, in 2005, Inprasitha introduced Japanese mathematics textbooks to support the teachers.

Inprasitha, Pattanajak, \& Inprasitha (2011) showed the characteristics of Japanese mathematics textbooks in dimension of mathematics contents, exercises, mathematical terms, and others. Firstly, mathematics contents in the textbooks were represented as mathematics activities that carry out by problem-solving approach. And they guided students' mathematical ideas that important for teachers to anticipate and observe their students' thinking. Secondly, almost most of exercises in the textbooks aim to check students' understanding more than repeatedly practice. And mathematical terms were nearly students' natural language.

Furthermore, Inprasitha (2015); Inprasitha, Pattanajak, \& Inprasitha (2011) 
suggested some key issues regarding the teaching and learning mathematics in Japanese mathematics textbooks. The textbooks provided teaching guide and had the sequence of subject matter represented nearly students' real world and mathematize to mathematical world that help teachers to design the lesson properly.

Although most teachers used the textbooks as the basic instructional material, different ways in using the textbooks are important to students' learning. Inprasitha (2015) and Changsri (2015) noted that teachers' using of textbooks that consists of mainly routine exercises, may be the cause of poor performance of Thai students in mathematics. And Plianram \& Inprasitha (2012) showed the difference on approach to use Thai and Japanese mathematics textbooks between Thai teachers before and during attend the project. After they attend the project, they more examine the textbooks with a "critical eye" to decide what and how to teach, and more created problems and questions to stimulate students' ideas.

Therefore, teachers' implementing mathematics textbooks with Lesson Study and Open Approach is important. Inprasitha (2015) suggested the teachers in the project about how to use the textbooks for designing the lesson as follows: 1) What are the mathematics contents in this lesson? 2) What is the students' real world in this lesson? 3) What is the purpose is hidden in the lesson? 4) What are students' ideas along with the reasons in this lesson? And 5) what are sequences of teaching that encourage students to solve problems by themselves in this lesson? Those suggestions for implementing the textbooks can proceed with the process of Lesson Study and Open Approach as Figure 2.

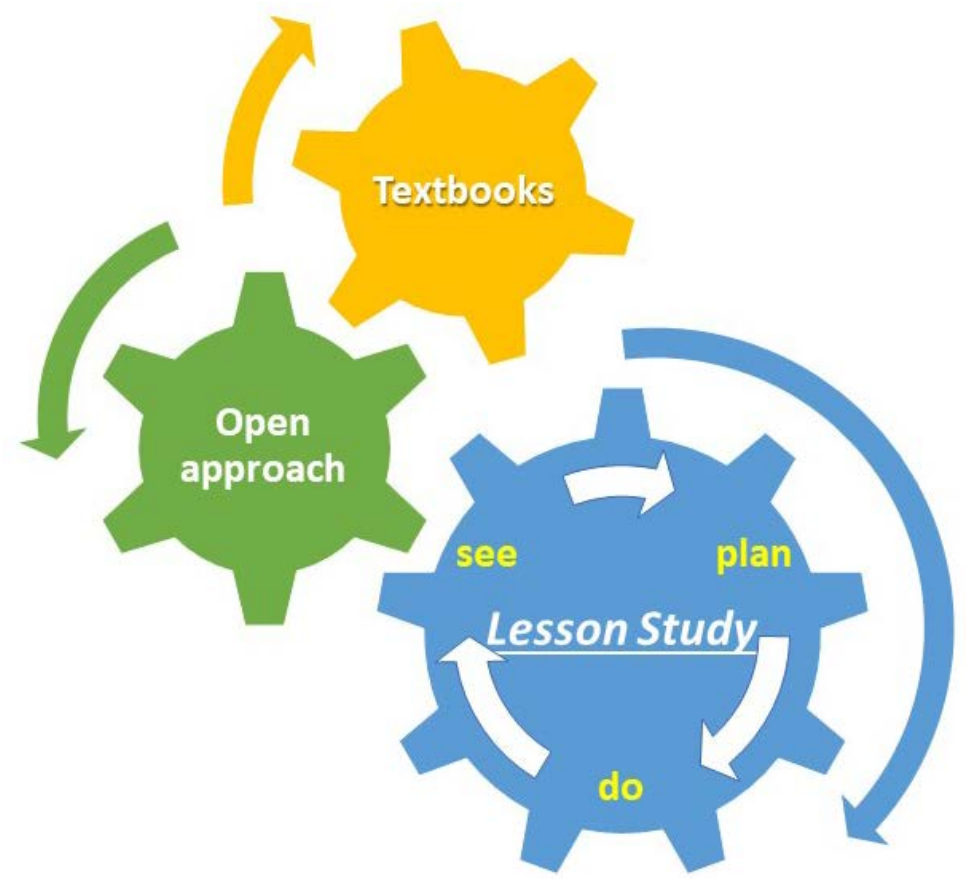

Figure 2. Implementing mathematics textbooks with lesson study and open approach by Inprasitha' approach $(2010,2015,2017)$. 


\section{Communities of Practice}

Inprasitha (2017) provided various activities for the community. In the project's schools, the first unit of community starts at teachers' team for each grade. It was called "classroom unit" including a group of teachers and administrator. They design the lesson by using the textbooks every week, observe their students' ideas in the classroom every day, and reflect the students' ideas every week. At the end of a semester, all of teachers in the project participated in the national open class activity, the workshop for teachers, and some of them can observe international open class and share with Japanese experts and other countries.

\section{Boundaries as a Challenging Idea in the Communities of Practice}

Since 1991, Jean Lave and Etienne Wenger proposed the term communities of practice in their book, Situated Learning. They situated learning in forms of social participation (Lave \& Wenger 1991). In 1998, Wenger expanded on the concept in his book, Communities of Practice. He described three dimensions of practice as the property of a community: a mutual engagement, a joint enterprise, a shared repertoire (Wenger, 1998).

In 2002, Wenger, McDermott \& Snyder (2002) defined "communities of practice" as are groups of people who share a concern, a set of problems, and who deepen their knowledge and expertise in this area by interacting ongoing basis. They don't necessarily work together every day, but they find value in their interaction. There are various definitions and forms of communities of practice, knowing these various definitions and forms are important to recognize in the communities.

Wenger, McDermott and Snyder (2002) suggested the first skill of community development that is to be able to "see" form of the communities of practice, such as "size", "period of time", "place", and so on. Especially, "seeing" form of the community base on inside and across boundaries of community as follows;

1) Within business: as a group of people within a business that address recurring sets of problems or interesting issues. And they try to share how to solve it together.

2) Across business units: as a group of people who work in different business unitsformsa community of practice to keep in touch and interest some of problems or interesting issues. And they try to share how to solve it together.

3) Across organization boundaries: for extended network, community of practice often become useful precisely by crossing organization boundaries. If they are interested in some of problems or issues, they can form a community to fix the problem.

As the definition of community of practice by Lave \& Wenger (1991) and Wenger, McDermott \& Snyder (2002), we defined the community of teachers' implementing mathematics textbooks with Lesson Study and Open Approach as are groups of people who interested in knowledge of students' ideas and improved the knowledge by using the textbooks to design the lesson and anticipate 
students' ideas, teach the lesson and observe students' ideas, and reflect on the lesson and students' ideas. And seeing form of the community was defined by Wenger, McDermott \& Snyder (2002) as follows.

1) Within school: as a group of people who work in a school together that are interested in the knowledge of students' ideas. They improved the knowledge by using the textbooks to design the lesson and anticipate students' ideas, teach the lesson and observe students' ideas, and reflect on the lesson and students' ideas.

2) Across schools: as a group of people who work in different schools that forms a community to keep in touch and interest the knowledge of students' ideas. They improved the knowledge by using the textbooks to design the lesson and anticipate students' ideas, teach the lesson and observe students' ideas, and reflect on the lesson and students' ideas.

3) Across organization boundaries: as a group of people who work in different organizations, such as, schools, universities, and so on. They form a community to keep in touch and interest the knowledge of students' ideas. They improved the knowledge by using the textbooks to design the lesson and anticipate students' ideas, teach the lesson and observe students' ideas, and reflect on the lesson and students' ideas.

\section{Methodology}

The participants in this study were 2 expert teachers (as teacher A and teacher B) in 2 project schools. The school of teacher A located in the northern part of Thailand. The school of teacher B located in the northeast part of Thailand. They were first-grade teachers who had teaching experiences for more than 25 years. Teacher A has been participating in the project school of mathematics teachers professional development using Lesson Study and Open Approach and implementing the textbooks since 2009. And teacher B has been participating in the project since 2006. They consistently participate in the project's activities.

We observed during their classroom instructions in mathematics and their participation in the project's activities in 2017 school year, and interviewed after their join in the project's activities.

The activities of the project in 2017 school year, that using Lesson Study and Open Approach and implementing the textbooks, consisting of open class for school network, the national open class, and workshop for the project's teachers.

Inprasitha provided various activities to improve teachings' teachers, such as the workshop that provide new ideas or practice for teachers properly, especially, the open class activities that provide opportunities for teachers to teach in public, get some suggestions from other observers, observe other classrooms to improve their observation.

The open class activities in Thailand are special activity regarding to instructional demonstration, a group of people who design the lesson, teach and observe the lesson, and reflect on the lesson together.

The mathematics textbooks for this study were Japanese mathematics textbooks 
(Thai version) for elementary school levels, and consisting of mathematics activities, flow of lesson, and students' mathematical ideas.

The data were collected by interviewing and observing in the classroom by using video recording in 2017 school year. The data were analyzed based on Wenger, McDermott, \& Snyder (2002)'s framework of the community of practice.

\section{Results}

The results showed that the 2 expert teachers participated in the community which has been 3 boundaries as following below.

\section{1) Within school}

We found that their school formed a school team consisting of a school principal and 1st - 6th grade teams. A teacher and an observer teacher were composed for each grade team. They shared knowledge regarding students' ideas by practicing as follows:

- Every week, the grade team collaboratively designed the lessons follow 4 steps of Open Approach. They created mathematics problems for $4-5$ lessons in a week by their interpretation of the textbooks. After that, they shared anticipating students' ideas and how to managing their students' ideas.

- The grade team collaboratively observed students' ideas occurred in their classroom.

- Lastly, school team collaboratively reflected on the lessons and share about students' ideas occurred in the classroom and what they learned from challenges every week.

Additionally, we would give an example of this boundary of within school.

\subsection{Teacher A Case}

Teacher A and teacher student were composed of 1st grade team. The role of teacher A is a classroom teacher and the role of teacher student is an observer. They designed lesson on "Introduction of Numbers" for first grade by using the textbook as shown in Figure 3.

They shared knowledge regarding students' ideas by practicing as follows:
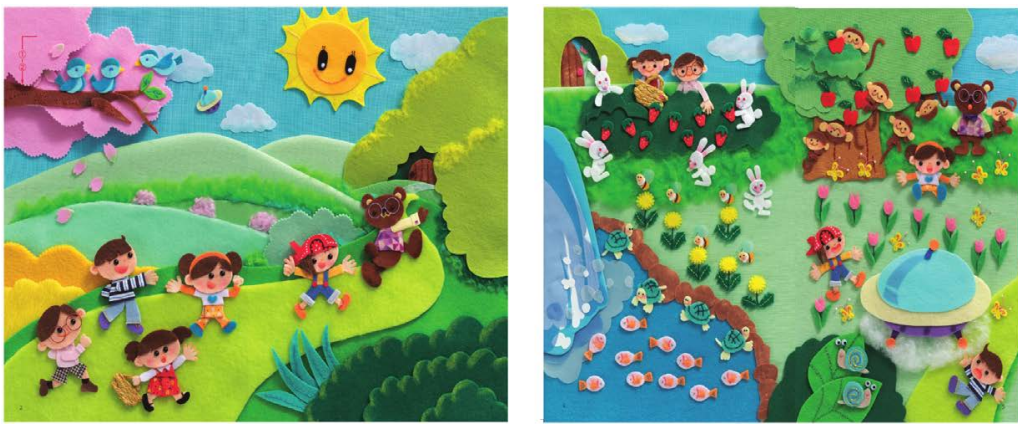

Figure 3. Example of Japanese mathematics textbook (Thai version) on "Introduction of Numbers" for first grade, p. 2-5. 
- They began to consider in the textbook and shared what they understand about the situation as Item 1 .

Teacher Student: It introduced numbers through the picture about trekking to the forest and seeing a lot of animals or something.

Teacher A: Our students never trekked to the forest. Last year, we planned the lesson and changed the story to "going to the zoo."

So, they created a mathematics problem as "Today, we will go to the zoo (teachers show the picture). What animals are in the picture and where are they?" This lesson aimed at students who can see many groups of animals.

Next, they anticipated students' ideas as "a lot of fishes in the swamp; many turtles near the swamp; bees are close to the flowers; rabbits pick a strawberry; monkeys pick an apple; butterflies are flying; snails are on a leaf".

Before preparing materials for this lesson, they shared about how students represent their ideas. Teacher A said asking students to draw animals on a paper sheet, then represent it in the classroom.

- Teacher A taught and observed students' ideas in the classroom with the students. The students found "fishes, turtles, bees, rabbits, monkeys, butterflies, and snails" and point round those animals on the picture. Then, teacher A asked students to draw those animals on their sheet.

- In the reflection stage, they participated in school team to reflect their classroom. They shared about students' ideas occurred in the classroom. They discussed how to connect students' ideas to the aim of lesson. Teacher A said students just draw the animals but not guaranty that they understand that the group of fish is important.

After the first week, teacher A's role changed to be an observer and the teacher student's role changed to be a classroom teacher.

\section{2) Across schools}

As the boundary of within school, the expert teachers had opportunities to share their experience with others in their school. In the boundary of across school, the project's schools were supported to conduct the open class activity with neighboring schools in every semester by the project. The activity was composed of 1 - 2 demonstration classrooms that implementing textbooks with Lesson Study and Open Approach.

In 2017 school year, we found that the teachers participated in open class activity. Their schools were a host and conducted the activity with schools network. The activity was composed of 1 - 2 demonstration classrooms that implementing textbooks and conducting Lesson Study and Open Approach. They practiced like in boundary of within school. They formed special teams to design the lessons, then demonstrate the classroom and reflect on the lessons.

We found that their school formed a school team consisting of a school principal and 1 st - 6th grade teams. The teacher and an observe teacher were com- 
posed of each grade teams. They shared knowledge regarding students' ideas by practicing as follows:

- Every week, the grade team collaboratively designed the lessons follow 4 steps of Open Approach. They created mathematics problems for 4 - 5 lessons in a week by their interpretation of the textbooks. After that, they shared anticipating students' ideas and how to managing their students' ideas.

- The grade team collaboratively observed students' ideas occurred in their classroom.

- Lastly, school team collaboratively reflected on the lessons and share about students' ideas occurred in the classroom and what they learned from challenges every week.

Additionally, we would give an example of boundary of across schools.

\subsection{Teacher B Case}

In 2017 school year, teacher B's school, as a host school, managed the open class activity. The activity's participants were composed of 12 teachers of 2 neighboring schools, 17 students' parents, 1 educational supervisor, 1 director of primary educational service area, 10 teacher students, and 3 university experts. There are 2 demonstration classrooms, such as 1 st grade and 6th grade classroom.

Teacher B was an observer teacher in 1st grade team. The team was composed of a classroom teacher, 2 observer teachers (teacher B and teacher student), a school principal (who work in other schools), and 2 university experts.

They designed the lesson on "Comparing Lengths" for first grade. They interpreted the textbook as "Today, teachers have many objects and ask students to compare each pair of objects, which one is longer?” They prepared materials to follow that appeared in the textbook. The materials were composed of pairs of pencils, pairs of ropes, width-length of postcard, and width-length of book.

They anticipated students' ideas, for example, students directly compare a pair of pencils through holding them; putting them down on table and concern endpoint of them. Students compare width and length of postcard through folding the postcard and concern endpoint of it.

In the part of reflection, the teacher shared about students' idea of comparing width-length of postcard. She said the students compared size of picture on the postcard.

\section{3) Across organization boundaries}

Every year, the 2 teachers participated in the national open class and the workshop for project's teachers with their schools and universities network.

The national open class was conducted by the project. The participants were composed of school teachers, school principals, teacher students, graduate students, university experts, and others who interested in the activity, totaled about 900 participants. There were 2 important activities, such as special lecture by experts, and demonstration classrooms on various subjects.

The workshop for project's teachers was conducted by the project. The par- 
ticipants were composed of school teachers, school principals, teacher students, graduate students, and university experts that focused on the participants of project. There were 3 important activities, such as special lecture by experts, workshop on lesson plan, and demonstration classrooms on mathematics.

Additionally, we would give an example of boundary of across schools.

Teacher A and teacher B participated in the workshop for project's teachers at Chiang Rai province, the northern part of Thailand. The participant were composed of school teachers, school principals, teacher students, graduate students, and university experts.

Firstly, they had an opportunity to update new ideas for teaching from the special lecture on "Kyozai Kenkyu in Lesson Study and Open Approach by Inprasitha (2017)".

Secondly, they joined the workshop on designing plan for first grade with other teachers and experts by using the textbooks. They collaboratively planed the lesson on "number 6" by interpretation on page $16-17$ in the textbook. They shared their experience on this lesson together. Teacher A said that this lesson aims to grouping of six. They created problem situation "Let's talk about happy birthday party in the picture: 1) drawing the objects that number of them are equal to the number of blue cups and 2) drawing blocks are equal to number of the objects"

Lastly, they might be not a representative of the team to reflect the classroom, but they had the opportunity to learn from others in session of observation and reflection the demonstration classroom. Teacher A said that "the aims of this lesson are students understand number 6 by using various of representation and comparing with number 5 that they had been learned from previous lesson. As the expert reflected on students' ideas about how the patterns of objects are difference (as Figure 4). I think I should deeply observe their ideas and consider in the textbook more."

\section{Concluding Remark}

For "seeing" boundaries of the community of teachers' implementing mathematics textbooks with Lesson Study and Open Approach based on Wenger, McDermott and Snyder (2002), it revealed that the 2 teachers participated in the community which has been 3 boundaries: within school, across schools, and across organization boundaries as Figure 5.

Each boundary, the teachers had opportunities to learn students' ideas from their classrooms, textbooks' views, teachers' views when they participated in boundary of within school. And they had opportunities to learn more from other classroom, experts' view and other when they participated in boundary of across schools, and across organization boundaries. That helps them to think about how to improve their practices.

This research focused only on domain of knowledge regarding students' ideas. At the same time, we founded interesting domains for further research, such as 

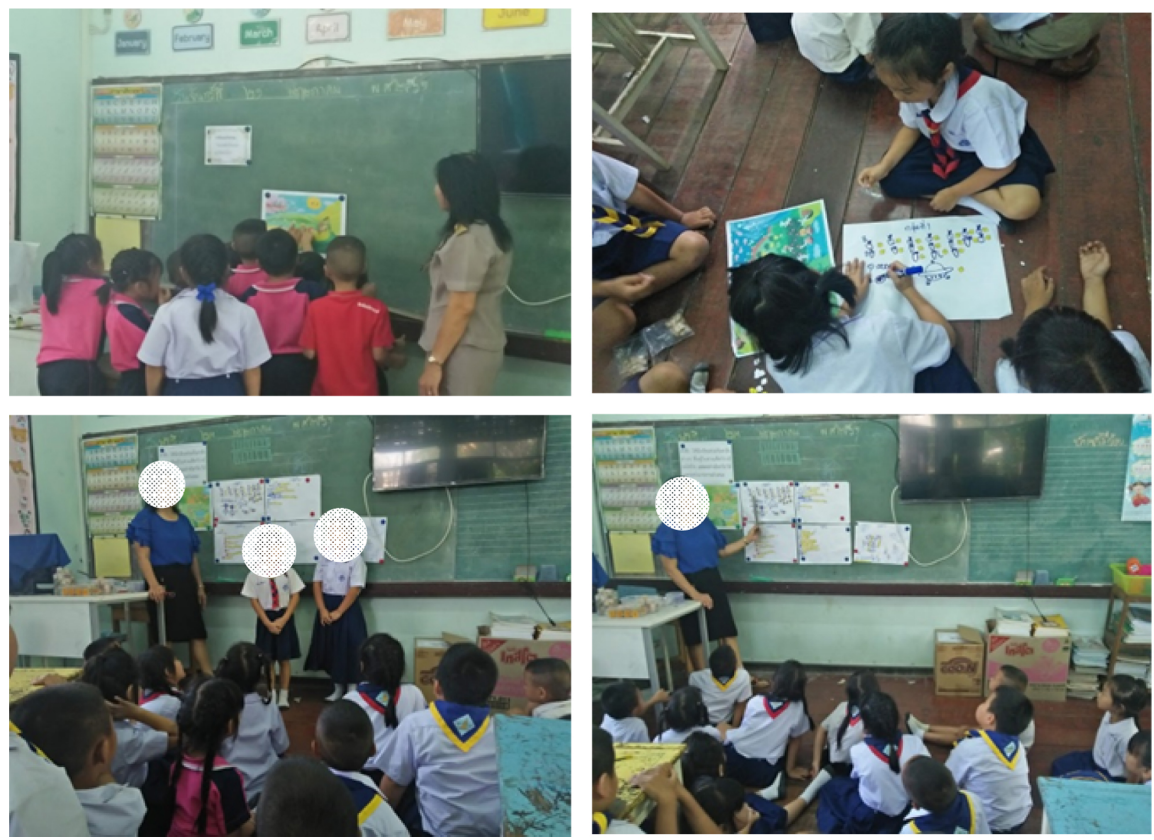

Figure 4. Example of a classroom in the boundary of within school.

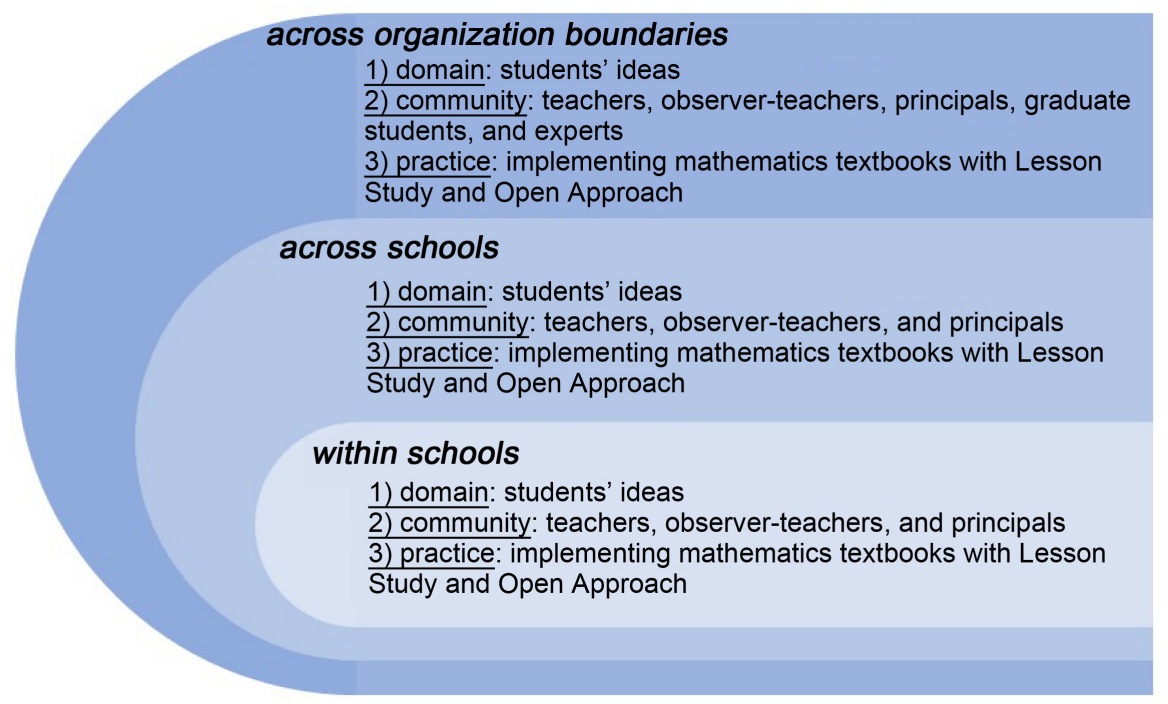

Figure 5. Boundaries of the community of teachers' implementing mathematics textbooks with lesson study and open approach.

knowledge of mathematics contents, teaching, designing materials, and so on.

In addition, the community of teachers' implementing mathematics textbooks with Lesson Study and Open Approach had support grant and activities by the Center for Research in Mathematics Education, and Institute for Research and Development in Teaching Profession for ASEAN, Khon Kaen University. Inprasitha (2015) provided various activities for teachers and other members in the community, such as school principals, graduate students, experts, and so on, that interested in further research.

In future research, we have a few suggestions. Firstly, this study we focus on 
limit of the participants, for the future study should concern about the number of participants. Secondly, the community of Lesson Study and Open Approach in Thai context, they have various activities, this study focuses only on open class activities, but we found some point that impact. Therefore, we suggested focusing on other activities for future research.

\section{Acknowledgements}

This research is supported by the Centre of Excellence in Mathematics, the Commission on Higher Education, Thailand. We are deeply grateful to Center for Research in Mathematics Education, Faculty of Education, Khon Kaen University, the Students' Mathematical Higher Thinking Development Project in Northeastern Thailand, Institute for Research and Development in Teaching Profession for ASEAN, and Thailand Society of Mathematics Education for conducting Lesson Study and Open Approach in Thai context more than 15 years.

\section{Conflicts of Interest}

The authors declare no conflicts of interest regarding the publication of this paper.

\section{References}

Changsri, N. (2015). First Grade Students' Mathematical Ideas if Addition in the Context of Lesson Study and Open Approach. In Conference Proceedings of ICMI 23: Primary Mathematics Study on Whole Numbers (pp. 60-67). Macau.

Inprasitha, M. (1997). Promblem Solving: A Basis to Reform Mathematics Instruction. Journal of the National Research Council of Thailand, 29, 221-259.

Inprasitha, M. (2010). One Feature of Adaptive Lesson Study in Thailand-Designing Learning Unit (pp.193-205). Paper Presented at the 45th Korean National Meeting of Mathematics Education, Gyeongju, Korea: Dongkook University.

Inprasitha, M. (2011). One Feature of Adaptive Lesson Study in Thailand: Designing a Learning Unit. Journal of Science and Mathematics Education in Southeast Asia, 34, 47-66.

Inprasitha, M. (2015). Lesson Study: Challenges in Mathematics Education. Toh Tuck Link, Singapore: World Scientific Publishing. https://doi.org/10.1142/7045

Inprasitha, M. (2017). Lesson Study and Open Approach: 15 Years of Mathematics Teaching Innovation in Thailand. Khon Kaen, Thailand: Institute for Research and Development in Teaching Profession for ASEAN. (In Thai)

Inprasitha, M., Pattanajak, A., \& Inprasitha N. (2011). How Do Our Teachers Use Our Textbooks? Paper Presented at APEC-Tsukuba International Conference V. http://www.criced.tsukuba.ac.jp/math/apec/apec2011/17-18/Thailandreport.pdf

Lave, J., \& Wenger, E. (1991). Situated Learning: Legitimate Peripheral Participation. Cambridge: Cambridge University Press. https://doi.org/10.1017/CBO9780511815355

Plianram, S., \& Inprasitha, M. (2012). Exploring Elementary Thai Teachers' Use of Mathematics Textbook. Creative Education, 3, 692-695.

https://doi.org/10.4236/ce.2012.36103 
Shimizu, S., \& Watanabe, T. (2010). Principles and Processes for Publishing Textbooks and Alignment with Standards: A Case in Japan. APEC Conference on Replicating Exemplary Practices in Mathematics Education 2010, Suratthani, Thailand.

Takahashi, A. (2015). Lesson Study: An Essential Process for Improving Mathematics Teaching and Learning. In M. Inprasitha (Ed.), Lesson Study: Challenges in Mathematics Education (pp. 51-58). Toh Tuck Link, Singapore: World Scientific Publishing. https://doi.org/10.1142/9789812835420_0004

Wenger, E. (1998). Communities of Practice: Learning, Meaning, and Identity. Cambridge: Cambridge University Press. https://doi.org/10.1017/CBO9780511803932

Wenger, E., McDermott, R., \& Snyder, W. M. (2002). A Guide to Managing Knowledge: Cultivating Communities of Practice. Boston, MA: Harvard Business School Publishing. 